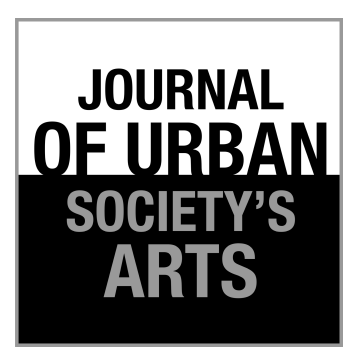

Volume 3 Nomor 2, Oktober 2016: 57-63

\section{Pelestarian Adat Semende di Desa Ulu Danau, Provinsi Sumatera Selatan}

Hatta Setiawan dan Cecep Darmawan

Program Studi Pendidikan Kewarganegaraan

Program Pascasarjana Universitas Pendidikan Indonesia Bandung

Jln. Dr. Setiabudhi 229, Bandung 40154

Tlp. 081928816166, E-mail: ataonee@gmail.com

\begin{abstract}
ABSTRAK
Penelitian ini bertujuan untuk mengetahui upaya-upaya yang dilakukan oleh masyarakat dan aparat desa dalam mempertahankan nilai-nilai luhur yang terdapat dalam aturan adat Semende yang ada di lingkungannya. Metode etnografi dengan pendekatan kualitatif digunakan untuk mengumpulkan data melalui observasi, wawancara, dan dokumentasi, serta dianalisis melalui reduksi data, penyajian, hingga penarikan kesimpulan. Hasil penelitian menunjukkan bahwa masyarakat Desa Ulu Danau memberikan kelonggaran dalam pelaksanaan adat, dan aparat desa telah mulai berupaya untuk mempertahankan aturan adat dengan memaksimalkan peran para pemuka adat, tokoh masyarakat, dan warga.
\end{abstract}

Kata kunci: pelestarian adat, Semende, Ulu Danau

\begin{abstract}
The Efforts to Conserve Semende Customs in Ulu Danau Village, South Sumatera Province. This study aims to determine the efforts undertaken by the community and village officials in defending the noble values contained in the existing customs rules of Semende in the area. The ethnographic method with a qualitative approach is used to collect data through observation, interviews, and documentation, which are analyzed through data reduction, presentation, and finally can be drawn for conclusion. The results show that the villagers of Ulu Danau provide the concession for the implementation of custom, and the village officials have begun the efforts to maintain their custom rules to maximize the roles of traditional leaders, community leaders, and citizens.
\end{abstract}

Keywords: conserve customs, Semende, Ulu Danau

\section{Pendahuluan}

Berangkat dari Peraturan PerundangUndangan No. 6 Tahun 2014 Mengenai Desa dengan pertimbangan untuk melindungi hak tradisional masyarakat desa dengan tujuan luhur guna mewujudkan masyarakat desa yang adil, makmur, dan sejahtera, undang-undang ini menempatkan salah satu fokus yang harus dikembangkan, yaitu mengenai adat yang berada di dalam tubuh masyarakat desa. Sebagai upaya merespons amanat pemerintah yang tertuang dalam Undang-Undang No. 6 Tahun 2014 ini, Pemerintah Provinsi Sumatera Selatan mengeluarkan Peraturan
Daerah Provinsi Sumatera Selatan No. 4 Tahun 2015 tentang Pelestarian Kebudayaan Daerah. Perda daerah ini bertujuan untuk menjaga aset daerah dan menjamin terpeliharanya kebudayaan daerah yang ada di Provinsi Sumatera Selatan.

Masyarakat Provinsi Sumatera Selatan secara umum memiliki banyak kekayaan adat dan istiadat yang ada di setiap daerah. Salah satu suku yang terbesar yang berada di daerah Sumatera Selatan ialah Suku Semende. Suku ini merupakan salah satu suku asli atau suku pribumi di dataran Pulau Sumatera bagian selatan. Mayoritas kepercayaan yang dianut oleh masyarakat adat Semende ialah beragama Islam. Menurut para pemuka adat 
yang berada di Desa Ulu Danau, adat Semende itu dipengaruhi oleh budaya Islam sehingga sangat kental aroma silaturahmi di dalamnya. Hal ini disebabkan leluhur masyarakat adat Semende telah mengenalkan agama Islam sejak dulu kala.

Selain menjadikan agama Islam sebagai pedoman hidup, masyarakat adat Semende juga terkenal dengan beberapa adat yang tidak tertulis. Beberapa adat yang cukup dikenal di kalangan masyarakat daerah Sumatera Selatan ialah adat Tunggu Tubang, Jenang Jurai, dan adat Besundi Besundat Besingkuh. Adat Tunggu Tubang merupakan adat yang diperuntukkan kepada wanita tertua dalam sebuah keluarga yang berkewajiban untuk mengelola harta pusaka demi kepentingan pribadi dan membantu saudara-saudaranya hingga dapat hidup mandiri (Guspitawaty 2002).

Adat Jenang Jurai merupakan adat yang diperuntukkan kepada anak laki-laki dalam setiap keluarga yang berfungsi sebagai penyeimbang dan pengawas pelaksanaan kewajiban Tunggu Tubang dalam mengelola harta pusaka yang berupa kebun, sawah, dan rumah, selain itu Jenang Jurai juga memiliki peran sebagai pemimpin (Setiawan 2013).

Berdasarkan sifat adat yang sebagian besar tidak tertulis, adat rentan mengalami penyimpangan dan tidak membutuhkan rintangan besar untuk mengalami ketergerusan terhadap nilai-nilai yang terkandung di dalamnya (Seragih 1996). Berbagai penyebab ketergerusan tersebut lebih disebabkan oleh berbagai pencampuran budaya yang diakibatkan oleh percampuran penduduk dalam program transmigrasi pada masa lampau yang menyebabkan masyarakat hukum adat mengalami berbagai perubahan (Hadikusuma 2003).

Mengacu dari beberapa pendapat tersebut, pada era globalisasi pada saat ini sebenarnya dibutuhkan beberapa upaya konkret yang harus dilakukan oleh berbagai pihak. Budimansyah (2010) mengungkapkan mengenai dampak negatif dari globalisasi mencakup "seluruh aspek kehidupan bermasyarakat, berbangsa, dan bernegara. Di samping itu dapat pula memengaruhi pola pikir, pola sikap, dan pola tindak seluruh masyarakat Indonesia”.

Beberapa upaya konkret yang dapat dilakukan sebagai upaya mempertahankan adat dan istiadat adalah melalui upaya yang dilakukan dari dua sisi. Sisi pertama dibutuhkan upaya dari masyarakat sebagai ornamen utama yang melaksanakan adat, dan kedua; ialah sisi eksternal yaitu aparat pemerintah atau aparat desa sebagai penyokong atau lembaga yang berwenang memfasilitasi dan memperkokoh warisan leluhur yang ada di wilayah kewenangannya. Manfaat yang dapat diperoleh dalam mempertahankan adat yang ada di setiap daerah ialah sebagai upaya membangun sekaligus mempertahankan karakter masyarakat yang telah diwariskan dari generasi ke generasi.

Penelitian ini dilakukan untuk mengetahui berbagai upaya yang dilakukan oleh masyarakat untuk tetap mempertahankan dan melaksanakan adat yang telah diwariskan oleh para leluhur masyarakat tersebut. Penelitian ini juga mencoba mencari tahu peran aparat desa dalam mempertahankan adat yang ada di wilayah kewenangannya. Dalam rangka untuk mengetahui hal tersebut, penelitian dilakukan di salah satu desa yang terletak di Desa Ulu Danau, Kecamatan Sindang Danau, Kabupaten Ogan Komering Ulu Selatan, Provinsi Sumatera Selatan.

Metode yang digunakan dalam penelitian ini ialah metode etnografi dengan pendekatan kualitatif. Sebagaimana yang telah diungkapkan oleh Spradley (2007) dan Kuntjara (2006) mengenai etnografi, yaitu sebuah penelitian yang naturalistik dengan cara mendeskripsikan suatu kebudayaan yang diambil dari sudut pandang penduduk asli yang ada di wilayah tersebut.

Dipilihnya lokasi penelitian di Desa Ulu Danau ialah dikarenakan desa tersebut dianggap oleh peneliti sebagai salah satu desa yang belum terlalu besar terkena dampak globalisasi sehingga harapan untuk mendapatkan cara pandang hidup masyarakat mengenai adat Semende masih memiliki kadar yang sesuai dengan apa yang telah diwariskan oleh leluhur Desa Ulu Danau. Pertimbangan dipilihnya Desa Ulu Danau ialah: (1) Desa Ulu Danau masih belum terjangkau dari jaringan komunikasi seluler, (2) Desa Ulu Danau masih tergolong dalam masyarakat adat yang bersifat komun, yaitu masih bergantung dengan hasil alam.

Subjek penelitian dilakukan dengan menggunakan teknik purposive, yaitu dengan cara me- 
nentukan berbagai kriteria dalam menentukan informan. Beberapa kriteria yang ditetapkan adalah: (1) orang yang paham akan adat Semende, (2) memiliki pengetahuan mengenai adat Semende, (3) memiliki usia yang telah dewasa, (4) sehat secara jasmani dan rohani, dan (5) orang yang memiliki pengaruh di dalam masyarakat.

Pengumpulan data yang dilakukan dalam penelitian ini ialah melalui teknik observasi, wawancara, dan dokumentasi. Teknik analisis data dilakukan melalui teknik triangulasi melalui reduksi, penyajian, hingga penarikan kesimpulan.

\section{Hasil dan Pembahasan \\ Upaya Masyarakat}

Masyarakat yang dimaksud di sini ialah masyarakat yang berdiam di Desa Ulu Danau, Kecamatan Sindang Danau, Kabupaten Ogan Komering Ulu Selatan, Provinsi Sumatera Selatan. Masyarakat Ulu Danau merupakan masyarakat yang memercayai adat Semende sebagai tatanan hidup masyarakat Ulu Danau. Seperti yang telah dikemukakan sebelumnya bahwasanya masyarakat adat Semende memiliki adat yang hingga kini masih dilaksanakan. Beberapa adat yang hingga kini masih dilaksanakan oleh masyarakat Semende di Desa Ulu Danau ialah adat Tunggu Tubang, Jenang Jurai, dan adat Besundi Besindat Besingkuh. Adanya upaya-upaya yang dilakukan untuk mempertahankan keberadaan adat oleh masyarakat adat ialah dikarenakan masyarakat adat percaya bahwa ketika suatu adat dilepaskan, maka hal tersebut dapat merugikan dan akan dirasa sebagai sebuah perbuatan yang menghilangkan kebahagiaan (Dewantara 2013).

Beberapa fenomena ditemukan dalam penelitian ini mengenai munculnya beberapa upaya yang dilakukan oleh masyarakat untuk tetap mempertahankan adat itu sendiri. Beberapa fenomena tersebut berasal dalam keadaan internal masyarakat adat itu sendiri. Fenomena yang pertama ialah adanya beberapa Tunggu Tubang yang bukan anak perempuan tertua di dalam sebuah keluarga. Kedua, ditemukannya fenomena urbanisasi atau istilah yang sering terdengar, yaitu merantau. Perantauan ini mayoritas dilakukan oleh anak laki-laki yang merupakan seorang calon penerus pemimpin di kalangan anggota kerabatnya. Fenomena yang ketiga ialah munculnya fenomena Ceblak Kate, fenomena ini ialah sebuah fenomena yang timbul akibat pergaulan anak atau sebuah perbuatan hasil pencontohan dari hal-hal yang tidak baik. Sesuai dengan istilah yang digunakan ialah istilah Ceblak Kate yang berarti sering digunakannya kata-kata yang tidak baik oleh anak-anak dalam bergaul dalam keseharian. Untuk mengatasi berbagai fenomena yang sebenarnya telah muncul sejak dulu di dalam masyarakat adat memunculkan berbagai upaya yang dilakukan oleh masyarakat untuk dapat mempertahankan adat dan istiadat yang ada di lingkungan masyarakat Ulu Danau itu sendiri. Beberapa upaya tersebut antara lain ialah:

\section{a. Memberikan Kelonggaran}

Kelonggaran ialah sebuah istilah yang digunakan oleh peneliti untuk menggambarkan adanya sebuah toleransi dari pihak keluarga ketika sang anak tidak dapat melaksanakan tugas adatnya. Toleransi ini diberikan dengan tujuan agar pelaksanaan adat yang seharusnya terus berlangsung dari generasi ke generasi tetap dapat dilaksanakan.

Kelonggaran yang pertama yang diberikan oleh sebuah keluarga ketika seorang anak perempuan tertua tidak dapat mengemban tugasnya sebagai Tunggu Tubang yang disebabkan berbagai hal yang antara lain dikarenakan seorang anak tertua perempuan tersebut bersuami orang yang berasal dari luar desa, ataupun dikarenakan suami seorang Tunggu Tubang tersebut memiliki pekerjaan di luar desa. Secara tidak langsung, dengan demikian hal ini akan memaksa seorang Tunggu Tubang harus ikut dengan suami keluar desa dan tidak dapat melaksanakan tugasnya sebagai Tunggu Tubang, yaitu mengelola harta pusaka keluarga yang berupa kebun, sawah, dan mengurus rumah. Keadaan semacam ini akan memberikan sebuah kekosongan fungsi dalam adat, yaitu tidak adanya orang yang akan mengurus sekaligus mengelola harta pusaka. Untuk mengisi kekosongan ini anggota kerabat akan berunding untuk memutuskan seseorang yang akan mengisi kekosongan fungsi adat tersebut.

Keputusan yang diambil ketika perundingan dilakukan oleh para kerabat untuk mengisi 
pemegang adat Tunggu Tubang yang ditinggalkan oleh anak tertua tersebut ialah dengan melihat kesiapan dari saudara-saudara perempuan yang berada di dalam keluarga tersebut. Pertimbangan yang paling mendasar dalam memutuskan siapa yang berhak mengisi jabatan adat Tunggu Tubang ketika terjadi kekosongan tersebut ialah seorang saudara perempuan yang paling membutuhkan dorongan ekonomi atau dalam kata lain ialah seseorang yang paling memerlukan hak pengelolaan harta pusaka keluarga untuk memperbaiki perekonomian di dalam keluarganya.

Kelonggaran yang kedua ialah kelonggaran yang diberikan kepada para Jenang Jurai yang pergi merantau yang notabene merupakan pengawas atau penyeimbang Tunggu Tubang dalam melaksanakan hak kelola terhadap harta pusaka keluarga, sekaligus sebagai pemimpin bagi para kerabat-kerabatnya. Merantaunya seorang Jenang Jurai ke luar desa yang dikarenakan tuntutan adatnya sebagai seorang pemimpin di kalangan para kerabat memaksa para Jenang Jurai harus memperoleh pendidikan dan wawasan yang cukup agar dapat melaksanakan fungsinya sebagai pemimpin. Banyaknya para calon Jenang Jurai yang merantau ke luar desa untuk mengenyam pendidikan di kota menyebabkan berbagai hal yang tidak terduga terjadi. Tidak sedikit dari para calon Jenang Jurai tersebut tidak kembali ke desa untuk menjalankan fungsi adat yang akan diembannya. Tidak sedikit dari para calon Jenang Jurai yang menetap di negeri rantau dengan alasan telah memperoleh pekerjaan di luar desa. Meskipun sebenarnya adat ini tidak dikhususkan kepada anak laki-laki tertua, sedikit banyak merantaunya para laki-laki dari desa membuat para kerabat untuk mengambil kebijakan atau solusi untuk para Jenang Jurai yang berada di luar desa. Kelonggaran yang diberikan kepada para Jenang Jurai yang berada di luar desa ialah bahwa dirinya tetap mengemban tanggung jawab sebagai pemimpin di dalam kalangan kerabatnya dengan catatan bahwa ketika dirinya dibutuhkan oleh para kerabat di desa untuk menyelesaikan sebuah masalah, maka dirinya harus pulang ke desa dalam waktu beberapa hari hingga persoalan diselesaikan dan ditemukan solusi atau jalan keluarnya.

Kelonggaran ini diberikan kepada para Jenang Jurai yang pergi merantau dikarenakan sebagai konsekuensi dari aturan adat yang menuntut bahwa anak laki-laki harus dapat hidup mandiri tanpa mengganggu keberadaan harta pusaka yang hak kelolanya diamanatkan kepada seorang anak tertua perempuan (Tunggu Tubang). Prinsip yang dijunjung tinggi oleh masyarakat adat Semende di Desa Ulu Danau ini ialah bahwa kodrat laki-laki merupakan sebuah kodrat yang harus memimpin dan kodrat perempuan ialah diistimewakan. Kodrat perempuan yang diistimewakan dalam hal ini ialah berarti bahwa kodrat perempuan itu ialah sebuah kodrat yang suci dan membutuhkan perlindungan dari para saudara laki-lakinya sehingga saudara perempuan tidak pernah luput dari pengawasan para saudara laki-lakinya.

Dewantara (2013) mengungkapkan keistimewaan kodrat seorang perempuan ialah "Haruslah diketahui bahwa hidup perempuan itu barangkali mengandung titah Tuhan yang suci, dan seringkali menimbulkan rintangan dan bahaya dalam hidup, serta nyata sekali bersifat perbuatan setan. Memang benar, di mana ada kesucian, di situlah iblis terdapat". Ungkapan tersebut jelas mengindikasikan bahwa perempuan di dalam kalangan masyarakat adat ataupun pandangan dari sisi budaya merupakan sebuah titah suci yang dikaruniakan oleh Tuhan kepada makhluknya, yaitu perempuan.

\section{b. Rerabe}

Dalam menanggapi fenomena yang ketiga, yaitu sebuah fenomena yang muncul di kalangan masyarakat adat Semende di desa Ulu Danau ialah fenomena Ceblak Kate. Fenomena ini ialah sebuah fenomena yang dianggap oleh masyarakat adat Semende sebagai sebuah pelanggaran terhadap norma sosial, yaitu menggunakan kata-kata yang tidak baik atau menggunakan kata-kata yang tidak layak untuk diucapakan kepada orang lain ketika sedang berinteraksi atau berkomunikasi antarsesama.

Penggunaan kata-kata yang tidak layak ataupun perkataan yang tidak pantas untuk 
diucapkan sebenarnya bukanlah sebuah fenomena yang hanya terjadi di Desa Ulu Danau, namun fenomena ini sudah sangat merebak di dalam kehidupan masyarakat, khususnya di kalangan generasi muda. Di dalam pergaulan generasi muda pada saat ini, menggunakan katakata yang tidak layak sudah menjadi sebuah tata cara generasi muda bergaul di dalam kehidupan sehari-hari dengan tujuan agar dianggap keren. Anggapan-anggapan inilah yang menjadi dasar utama membudayanya sebuah perilaku tersebut, meskipun pada saat ini telah mulai dianggap sebagai sebuah fenomena yang telah membudaya di kalangan generasi muda, namun tidak sedikit para anak muda yang masih kukuh mengikatkan dirinya dengan norma sosial yang ada di lingkungannya (civic commitment).

Pertunjukkan Rerabe ini ialah sebuah pertunjukan yang menggambarkan seseorang yang berpakaian tidak teratur dan sungguh tidak sedap dipandang mata. Sosok Rerabe ini ialah sebuah sosok pembelajaran kepada anggota masyarakat terutama kepada anak-anak agar berperilaku baik terhadap sesama jika tidak ingin menjadi seperti apa yang digambarkan oleh Rerabe tersebut. Perhelatan Rerabe ini digelar ketika akan menjelang Hari Raya Idul Fitri atau semalam sebelum Hari Raya Idul Fitri.

Hal ini bertujuan untuk mengingatkan anggota masyarakat terhadap kejahatan-kejahatan yang pernah dilakukan agar segera disucikan kembali. Perhelatan Rerabe ini sesuai dengan apa yang dikemukan oleh Setiady (2009) bahwa masyarakat adat memiliki sifat konkret, yaitu: "Konkret, di dalam arti berpikir yang tertentu senantiasa dicoba dan diusahakan supaya hal-hal yang dimaksudkan, diinginkan, dikehendaki atau akan dikerjakan, ditransformasikan atau diberi wujud suatu benda, diberi tanda yang kelihatan baik langsung maupun hanya menyerupai objek yang dikehendaki”. Hadikusuma (2003) memberikan penjelasan mengenai sifat masyarakat adat konkret, yaitu konkret artinya jelas, nyata, berwujud. Pendapat Molan (2015) juga mendefinisikan bentuk konkret dalam sebuah budaya ialah level konkret. Level ini adalah level paling visibel dan paling berwujud (tangible) dari budaya, dan mencakup dimensi pada level yang paling berada di permukaan.

Terdapat suatu rasa enggan sebuah masyarakat dalam melepaskan suatu adat yang dianggap akan mendatangkan sebuah kesukaran dan merugikan keberlangsungan hidupnya pada masa yang akan datang. Hal ini menyebabkan timbulnya berbagai upaya yang dilakukan oleh kalangan masyarakat untuk memastikan tetap terjaganya keberlangsungan adat di dalam suatu masyarakat. Seperti halnya yang dilakukan masyarakat Semende yang ada di Desa Ulu Danau dengan memberikan berbagai kelonggaran adat, dengan cara mengantisipasi ataupun memberikan hak yang sama kepada setiap anak yang tergantung dari kesiapan seorang anak dalam menjalankannya, merupakan salah satu sikap masyarakat adat yang tetap menjunjung tinggi pergaulan hidup ke luar. Hal ini digambarkan oleh Seragih (1996) bahwa "tiap-tiap anggota kelompok pada umumnya berkeyakinan suatu tindakan seorang anggota tidak hanya akan dirasakan oleh anggota-anggota sekelompok lainnya”. Sesuai dengan sifatnya yang bersikap ke luar, maka jika tidak dilakukakan upaya mempertahankan adat dari kelompok klan masingmasing, ditakutkan akan merambah kepada anggota masyarakat yang lainnya.

\section{Upaya Aparat Desa}

Aparat desa sebagai pelaksana tugas negara memiliki sebuah kewajiban untuk dapat menjaga keberadaan dan eksistensi kekayaan budaya yang terdapat di dalam masyarakatnya. Beberapa upaya yang dilakukan oleh aparat desa untuk mempertahankan keberadaan adat-istiadat yang ada di lingkungannya ialah memaksimalkan peran pemuka adat, tokoh masyarakat, dan warga desa. Nucci \& Narvaez (2015) menyatakan bahwa kelompokkelompok yang berperan penting dalam tubuh masyarakat ialah para profesional, pembuat kebijakan, pejabat penegak hukum, pemimpin gereja, anak muda, dan kelompok-kelompok warga peduli.

Bagi masyarakat adat, pemuka adat merupakan salah satu orang yang sangat berpengaruh di dalam masyarakat adat. Pemuka adat memainkan peran sebagai pentransfer pemahaman adat 
kepada warganya yang sesuai dengan aturan yang berlaku. Hal ini dikarenakan masyarakat adat menganggap bahwa individu-individu yang ada dalam masyarakat merupakan satu kesatuan yang menyatu dan bukan sebagai sebuah individu yang berdiri sendiri atau yang disebut dengan masyarakat yang bercorak komun (Seragih 1996).

Berbagai hal yang dilakukan aparat desa dalam menanggapi fenomena-fenomena yang terjadi pada saat ini ialah dengan memaksimalkan kinerja para pemuka adat untuk aktif menyosialisasian aturanaturan adat. Hal yang dilakukan oleh para pemuka adat ialah kembali menafsirkan atau mengkaji kembali ketentuan-ketentuan adat Semende sesuai dengan kitab acuan yang dipergunakan ialah kitab Simboer Tjahaja.

Pada proses pengatualisasian peran pemuka adat di dalam tubuh masyarakat, pemuka adat harus menafsirkan ketentuan adat yang disesuaikan dengan tantangan zaman sehingga adat dapat bergerak secara dinamis bukan malah sebagai sebuah aturan yang mengekang masyarakat.

Mengenai upaya aparat desa untuk memaksimalkan kembali peran para pemuka adat, tokoh masyarakat, serta terjalinnya hubungan intens dengan anggota mayarakat merupakan sebuah fenomena yang dahulunya pernah dilakukan oleh masyarakat adat Semende di Desa Ulu Danau. Terjalinnya hubungan yang baik antaranggota masyarakat dan para pemimpinnya merupakan bagian dari struktur pemerintahan adat kuno, yaitu sistem kemargaan. Gambar 1 merupakan skema struktur pemerintahan masyarakat adat kuno berbasis kemargaan.

\section{Skema Struktur Pemerintahan Adat Kuno}

Struktur ini ialah struktur pemerintahan masyarakat Semende yang memiliki kedekatan antara pejabat adat desa dan masyarakat desanya. Dalam struktur pemerintahan adat ini dipimpin oleh Pesirah dengan tiga wakilnya. Wakil pertama Pesirah ialah Pembarap, wakil keduanya ialah Krie, dan wakil ketiganya ialah Penggawe. Dalam struktur ini para pejabat adat desa tersebut tidak diperkenankan meninggalkan desa secara bersamaan. Hal ini ditujukan agar ketika masyarakat membutuhkan salah satu pejabat adat, maka pejabat adat tersebut siap melayani. Struktur ini secara otomatis akan saling menggantikan posisinya masing-masing dan saling mengisi. Seperti halnya ketika pemimpinnya sedang berurusan di luar desa, tanpa instruksi wakil pertama Pembarap akan mengisi tugas yang ditinggalkan oleh Pesirah, dan begitu seterusnya. Struktur ini merupakan struktur adat tradisional perihal pemerintahan yang benar-benar melayani masyarakat. Setiady (2009) menyatakan bahwa mengenai struktur kemargaan yang terdapat di Sumatera Selatan, yaitu: "Kepala marga di sini disebut Pesirah, dengan gelar Pangeran atau Depati, sedangkan Kepala Dusun disebut dengan Krio atau Mangku atau juga Prowatin. Para staf pembantu disebut Punggawa, Kepala Suku (Towo Suku)". Pendapat ini juga sejalan dengan hal yang digambarkan oleh Hadikusuma (2003) yang mengungkapkan bahwa marga-marga dikepalai "kepala marga (Pesirah) dan didampingi kerapatan adat marga yang anggota-anggotanya adalah para prowatin adat dan tua-tua masyarakat marga (Prasetya, 2002). Dalam menjalankan pemerintahan desa itu kepala

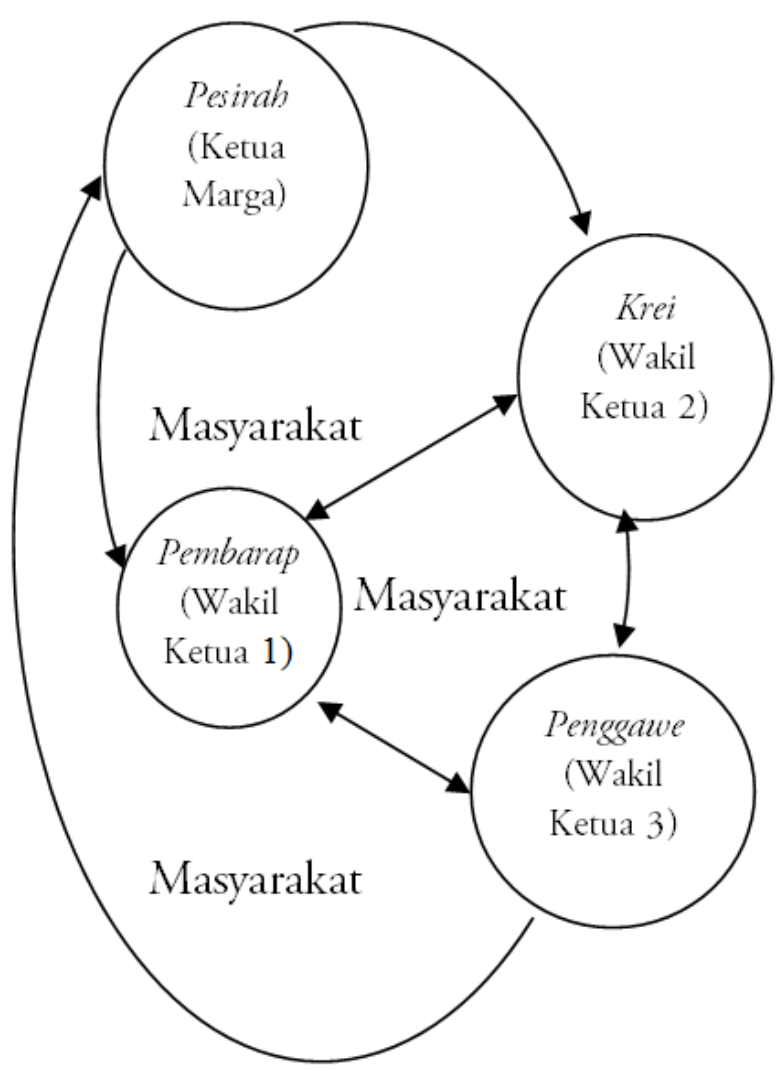

Gambar 1. Skema struktur pemerintahan adat kuno. (Sumber: Diolah oleh Penulis, 2016) 
marga dibantu oleh para Krio (kepala dusun), para Pemangku dan Punggawa”.

Struktur pemerintahan adat ini memiliki fungsi kontrol akan perilaku adat di masing-masing kelompok masyrakat yang dipimpin. Keempat pejabat adat ini sangat dihormati dan disegani oleh masyarakat karena kedekatannya dengan masyrakat yang seolah-olah tidak ada gap antara kedua sisi tersebut.

Insiatif aparat desa untuk meninjau ulang peraturan adat dan mencoba untuk mengembalikan norma-norma adat sebagaimana mestinya merupakan salah satu dari upaya untuk mengembalikan koordinasi masyarakat dengan pemimpinnya seperti apa yang dahulu pernah dilakukan dalam sistem struktur kemargaan, yaitu adanya Pesirah, Pembarab, Krei, dan Penggawe. Dalam sistem ini diberikan contoh bahwa hubungan antara masyarakat dan pemimpin haruslah berjalan dengan baik sehingga dengan adanya hubungan baik antara pemimpin dan masyarakat dapat menghasilkan sistem sosial yang baik juga.

\section{Simpulan}

Upaya-upaya pelestarian adat istiadat yang ada dalam adat Semende di Desa Ulu Danau dilakukan melalui dua sisi aspek yang saling berhubungan. Sisi pertama dilakukan melalui sisi masyarakat adat itu sendiri dan sisi kedua dilakukan melalui sisi eksternal, yaitu peran aktif aparat desa untuk menghidupkan adat yang ada di dalam lingkungannya. Upaya pelestarian yang dilakukan dari sisi masyarakat adalah adanya pemberian kelonggaran terhadap adat dari masyarakat itu sendiri yang berdasarkan insiatif masyarakat adat itu sendiri, serta melalui warisan leluhur, yaitu melalui kesenian budaya Rerabe. Berdasar sisi eksternalnya, maka aparat desa memainkan peran sebagai pelopor untuk memulai pelestarian adat.

\section{Ucapan Terima Kasih}

Ucapan terima kasih disampaikan kepada seluruh pihak yang telah berperan penting dalam penulisan penelitian ini, yaitu para warga masyarakat adat Semende di Desa Ulu Danau, pemuka adat, dan aparat desa yang telah membantu penulis untuk dapat menyelesaikan penelitian ini.

\section{Kepustakaan}

Budimansyah, D., 2010. Penguatan Pendidikan Kewarganegaraan Untuk Membangun Karakter Bangsa. Bandung: Widya Aksara Press.

Dewantara, K.H., 2013. Pemikiran, Konsepsi, Keteladanan, Sikap Merdeka (Kebudayaan II). Yogyakarta: UST Press.

Guspitawaty, E., 2002. 'Penyimpangan Sistem Pewarisan yang Terjadi pada Masyarakat Hukum Adat Semendo Pulau Beringin Kabupaten Ogan Komering Ulu Provinsi Sumatera Selatan." [Tesis], Universitas Dipenogoro.

Hadikusuma, H., 2003. Pengantar Ilmu Hukum Adat Indonesia. Bandar Lampung: Mandar Maju.

Kuntjara, E., 2006. Penelitian Kebudayaan. Sebuah Panduan Praktis. Yogyakarta: Graha Ilmu.

Melati, K R. 2014. "Pendidikan sebagai Perekrut dalam Komunitas Terbayang: Analisis Wacana dalam Film Denias Senandung di Atas Awan". Journal of Urban Society's Art, 1(2)2014, pp. 91-98.

Molan, B., 2015. Multikulturalisme Cerdas Membangun Hidup Bersama yang Stabil dan Dinamis. Jakarta: PT Indeks.

Nucci \& Narvaez, 2015. Handbook Pendidikan Moral dan Karakter (Handbook of Moral and Character Education). Bandung: Nusa Media.

Prasetya, Hanggar Budi. 2002. "Sebuah Komunitas Baru”.[Tesis] Prodi Antropologi Universitas Indonesia.

Seragih, D., 1996. Pengantar Hukum Adat Indonesia. Bandung: Tarsito.

Setiady, T., 2009. Intisari Hukum Adat Indonesia (Dalam Kajian Kepustakaan), Bandung: Alfabeta.

Setiawan, H., 2013. "Realisasi Fungsi Jenang Jurai yang Merantau Menurut Adat Semendo di Lingkungan Desa Uludanau Provinsi Sumatera Selatan."Universitas Negeri Yogyakarta.

Spradley, J.P., 2007. Metode Etnografi. Yogyakarta: Tiara Wacana. 